\title{
Arctic sea ice variability and trends, 1979-2010
}

\author{
D. J. Cavalieri and C. L. Parkinson
}

Cryospheric Sciences Laboratory/Code 615, NASA Goddard Space Flight Center, Greenbelt, MD 20771, USA

Correspondence to: D. J. Cavalieri (donald.j.cavalieri@nasa.gov)

Received: 14 February 2012 - Published in The Cryosphere Discuss.: 9 March 2012

Revised: 3 July 2012 - Accepted: 15 July 2012 - Published: 15 August 2012

\begin{abstract}
Analyses of $32 \mathrm{yr}$ (1979-2010) of Arctic sea ice extents and areas derived from satellite passive microwave radiometers are presented for the Northern Hemisphere as a whole and for nine Arctic regions. There is an overall negative yearly trend of $-51.5 \pm 4.1 \times 10^{3} \mathrm{~km}^{2} \mathrm{yr}^{-1}$ $\left(-4.1 \pm 0.3 \%\right.$ decade $\left.^{-1}\right)$ in sea ice extent for the hemisphere. The yearly sea ice extent trends for the individual Arctic regions are all negative except for the Bering Sea: $-3.9 \pm 1.1 \times 10^{3} \mathrm{~km}^{2} \mathrm{yr}^{-1}\left(-8.7 \pm 2.5 \% \mathrm{decade}^{-1}\right)$ for the Seas of Okhotsk and Japan, $+0.3 \pm 0.8 \times 10^{3} \mathrm{~km}^{2} \mathrm{yr}^{-1}$ $\left(+1.2 \pm 2.7 \% \mathrm{decade}^{-1}\right)$ for the Bering Sea, $-4.4 \pm 0.7 \times$ $10^{3} \mathrm{~km}^{2} \mathrm{yr}^{-1}\left(-5.1 \pm 0.9 \% \mathrm{decade}^{-1}\right)$ for Hudson Bay, $-7.6 \pm 1.6 \times 10^{3} \mathrm{~km}^{2} \mathrm{yr}^{-1}\left(-8.5 \pm 1.8 \%\right.$ decade $\left.^{-1}\right)$ for Baffin Bay/Labrador Sea, $-0.5 \pm 0.3 \times 10^{3} \mathrm{~km}^{2} \mathrm{yr}^{-1}(-5.9 \pm$ $3.5 \% \mathrm{decade}^{-1}$ ) for the Gulf of St. Lawrence, $-6.5 \pm 1.1 \times$ $10^{3} \mathrm{~km}^{2} \mathrm{yr}^{-1}\left(-8.6 \pm 1.5 \% \mathrm{decade}^{-1}\right)$ for the Greenland Sea, $-13.5 \pm 2.3 \times 10^{3} \mathrm{~km}^{2} \mathrm{yr}^{-1}\left(-9.2 \pm 1.6 \%\right.$ decade $\left.^{-1}\right)$ for the Kara and Barents Seas, $-14.6 \pm 2.3 \times 10^{3} \mathrm{~km}^{2} \mathrm{yr}^{-1}$ $\left(-2.1 \pm 0.3 \%\right.$ decade $\left.^{-1}\right)$ for the Arctic Ocean, and $-0.9 \pm$ $0.4 \times 10^{3} \mathrm{~km}^{2} \mathrm{yr}^{-1}\left(-1.3 \pm 0.5 \% \mathrm{decade}^{-1}\right)$ for the Canadian Archipelago. Similarly, the yearly trends for sea ice areas are all negative except for the Bering Sea. On a seasonal basis for both sea ice extents and areas, the largest negative trend is observed for summer with the next largest negative trend being for autumn. Both the sea ice extent and area trends vary widely by month depending on region and season. For the Northern Hemisphere as a whole, all 12 months show negative sea ice extent trends with a minimum magnitude in May and a maximum magnitude in September, whereas the corresponding sea ice area trends are smaller in magnitude and reach minimum and maximum values in March and September.
\end{abstract}

\section{Introduction}

Satellite passive microwave observations of the Earth's polar sea ice cover over the last three decades have provided the basis for studying its regional, seasonal, and interannual variabilities. The Arctic sea ice cover has exhibited a significant decline over this period (e.g. Parkinson et al., 1999; Vinnikov et al., 2006; Meier et al., 2007; Parkinson and Cavalieri, 2008; Stroeve et al., 2012). In contrast to the Arctic, the total Antarctic sea ice cover has increased somewhat from 1979 through 2010. Analyses of the Antarctic sea ice cover for this period are presented in a companion paper (Parkinson and Cavalieri, 2012). In this study we extend the 28 -yr (1979-2006) time series presented by Parkinson and Cavalieri (2008) and discuss the differences in the Arctic sea ice variabilities and trends observed principally between the 28 -yr and 32-yr periods. We also examine changes in trends among the 32-yr, 28-yr, and 18-yr periods, the latter from a study by Parkinson et al. (1999).

Figure 1 shows the 32-yr averaged sea ice concentration maps for March, the month of maximum sea ice extent on average, and for September, the month of minimum sea ice extent on average. Figure 1 also shows the locations of each of the nine Arctic regions analyzed in this study. Much background material about Arctic sea ice and the characteristics of each of the nine regions used in the analyses is given in Parkinson et al. (1999) and in Parkinson and Cavalieri (2008) and is not repeated here. The emphasis in this study is mainly on the changes that occurred from the previous 28-yr time series results to the current 32-yr results. In Sect. 2, we provide a brief description of the data sets used and the methods employed to derive the sea ice time series. In Sect. 3, we present the results of our analyses for sea ice extents and sea ice areas. In Sect. 4, we provide a comparison of trends 

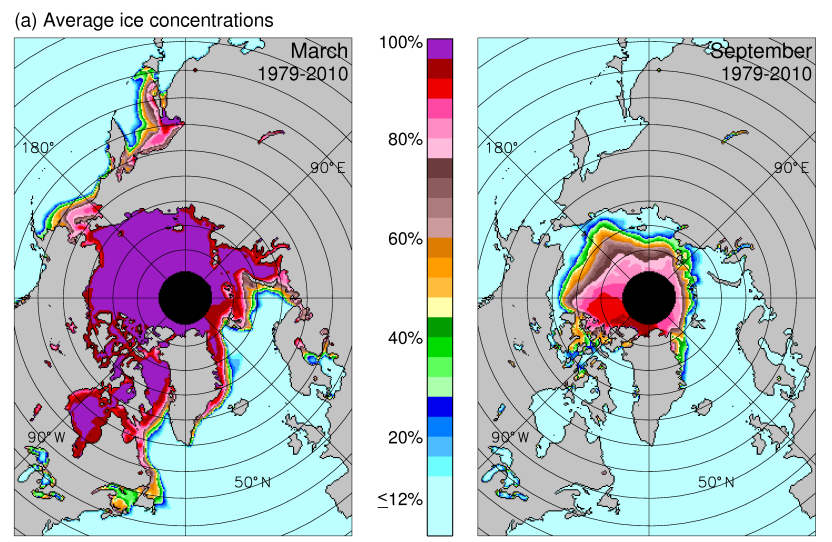

(b) Regions
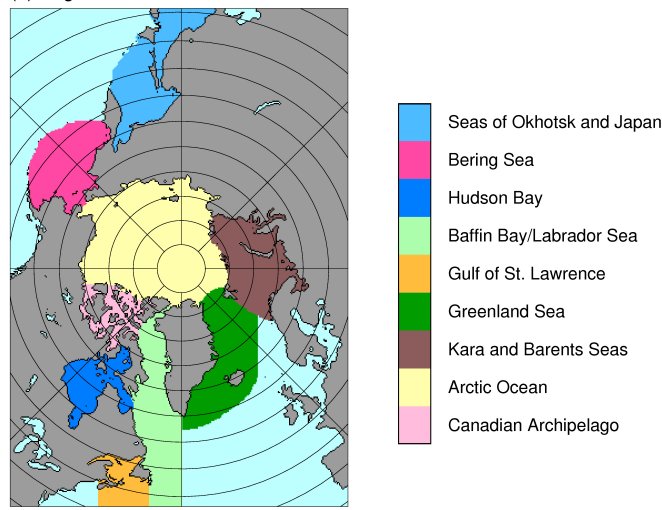

Fig. 1. (a) Maps of Northern Hemisphere March and September sea ice concentrations, averaged over the years 1979-2010, as derived from satellite passive-microwave observations. (b) Location map of the regions used in the analysis (updated Fig. 1 from Parkinson and Cavalieri, 2008).

from previously analyzed shorter time series. In Sect. 5, we present the main conclusions.

\section{Data sources and methods}

The data set from which the sea ice extents and areas are calculated consists of sea ice concentration maps derived from the radiances obtained from the following satellite microwave radiometers: the Nimbus 7 Scanning Multichannel Microwave Radiometer (SMMR), which operated from 26 October 1978 through 20 August 1987, the Defense Meteorological Satellite Program (DMSP) series of F8, F11, and F13 Special Sensor Microwave Imagers (SSMI), and the F17 Special Sensor Microwave Imager Sounder (SSMIS). The F8 SSMI operated from 9 July 1987 through 18 December 1991, the F11 SSMI from 3 December 1991 through 30 September 1995, and the F13 SSMI from 3 May 1995 through 31 December 2007. The F17 SSMIS provided data from 1 January 2008 through 31 December 2010.

The generation of a long-term, consistent time series of sea ice extents and areas is particularly challenging because of the use of different satellite sensors, each of which may differ in their measurement wavelengths, fields-of-view, angles of incidence, ascending node times, and calibrations. In a study of the consistency of long-term observations of oceans and ice from space, Zabel and Jezek (1994) found that ocean observations should be matched at the geophysical product level rather than at the sensor radiance level, an approach that was already in use by the sea ice community. Details of the approach, including filling data gaps, reducing land-to-ocean spillover effects, reducing weather effects over ice-free ocean, and finally matching sea ice extents and areas for each pair of overlapping sensors, are discussed by Cavalieri et al. (1999).

Starting with the Nimbus 7 SMMR, the data from each subsequent sensor were matched with the data from the previous sensor using the available period of overlap to minimize the differences. Although we did not have the desired complete year of overlap for each pair of sensors, we were able to reduce ice extent differences during periods of sensor overlap to $0.1 \%$ or less and ice area differences to $0.6 \%$ or less (Cavalieri et al., 1999). Most recently, we did have a complete year of overlap (2007) with which to match the F13 SSMI and F17 SSMIS sea ice extents and areas. A description of the methods used and the level of agreement obtained are provided by Cavalieri et al. (2012).

\section{Results}

Sea ice extents and areas are presented for the Northern Hemisphere as monthly averaged values, monthly deviations, and yearly and seasonally averaged values for the years 1979-2010 (Fig. 2). We present the monthly deviations of sea ice extents and areas for each of the nine Arctic regions: Seas of Okhotsk and Japan, Hudson Bay, Baffin Bay/Labrador Sea, the Gulf of St. Lawrence, the Greenland Sea, the Kara and Barents Seas, the Arctic Ocean, and the Canadian Archipelago (Fig. 3). Sea ice extent and area trends by month over the 32-yr period 1979-2010 are also presented (Fig. 4). Trends are presented both in $\mathrm{km}^{2} \mathrm{yr}^{-1}$ and in $\%$ decade ${ }^{-1}$ (Table 1). The $\mathrm{km}^{2} \mathrm{yr}^{-1}$ trend is simply the slope of the least squares fit line. The $\%$ decade $^{-1}$ trend is based on the slope of the least squares fit line and the 1979 value of that line.

For the purpose of providing a relative measure of the "significance" of the trends, we calculate a ratio $R$ of the estimated trend to its standard deviation. $R$ provides a continuous measure of "significance" and is less arbitrary than the standard $95 \%$ or $99 \%$ levels of statistical significance generally used. Nonetheless, these levels of significance are indicated in the trend tables to provide a reference for comparison with other published values. These levels of statistical significance are obtained using the Student's t-test with the null hypothesis of a zero trend and assuming 30 (32-2) degrees of freedom. The threshold values of $R$ corresponding 
to the $95 \%$ and $99 \%$ levels of statistical significance are 2.04 and 2.75 , respectively. Although the use of this statistical significance test has been criticized both for the use of the null hypothesis and the arbitrary levels of significance (e.g. Nicholls, 2001) and for issues related to the autocorrelation of the data (e.g. Santer et al., 2000), we still indicate these levels of statistical significance in the tables to provide a relative measure of the robustness of the trend.

\subsection{Sea ice extents}

Sea ice extent is defined as the cumulative area of all grid cells having at least $15 \%$ ice concentration. The reasons for using a $15 \%$ cutoff have been discussed previously by Parkinson and Cavalieri (2008). We first examine sea ice extent variabilities and trends for the Northern Hemisphere as a whole and then for each of the nine Arctic regions.

\subsubsection{Northern Hemisphere total}

A comparison of the 32-yr March and September maps of Fig. 1 with the corresponding maps for the $28-\mathrm{yr}$ period (Fig. 1 in Parkinson and Cavalieri, 2008) reveals a noticeable reduction in average ice concentrations in the central Arctic for September, whereas there are fewer noticeable differences in average ice concentration for March. This seasonal difference is reflected in the summer versus winter trends for both sea ice extents and areas discussed below.

Figure 2a shows the monthly average sea ice extents for the total Northern Hemisphere as well as the average seasonal cycle (Fig. 2a inset) based on monthly averages. Generally, the month of maximum extent is March, whereas the month of minimum extent is September. The three years with the largest March sea ice extents for the Northern Hemisphere were 1979, 1983, and 1982, having extents of 16.1, 15.9, and 15.8 million square kilometers, respectively. The three years with the smallest September sea ice extents were 2007, 2008, and 2010, with extents of 4.3, 4.7, and 4.9 million square kilometers, respectively.

Figure $2 \mathrm{~b}$ shows the sea ice extent monthly deviations for the November 1978-December 2010 (32 1/6 yr) period with an overall trend of $-51.4 \pm 1.9 \times 10^{3} \mathrm{~km}^{2} \mathrm{yr}^{-1}$. The largest negative excursion from the trend line occurs in September 2007, which had the smallest sea ice extent $\left(4.32 \times 10^{6} \mathrm{~km}^{2}\right)$ for the 32 -yr period. The overall trend is $14 \%$ more negative than the corresponding trend for the 28-yr period (Parkinson and Cavalieri, 2008).

Figure $2 \mathrm{c}$ shows both the yearly and seasonal trends for the Northern Hemisphere for the 32-yr period 1979-2010. The trend values are provided in Table 1. All the trends are negative with increasingly larger negative trends from spring, winter, autumn, and summer. A comparison of seasonal trends from the 28-yr to 32-yr period shows that for the $32-\mathrm{yr}$ period the magnitude of the negative trend for summer has increased by $31 \%$, for autumn has increased by $20 \%$, for
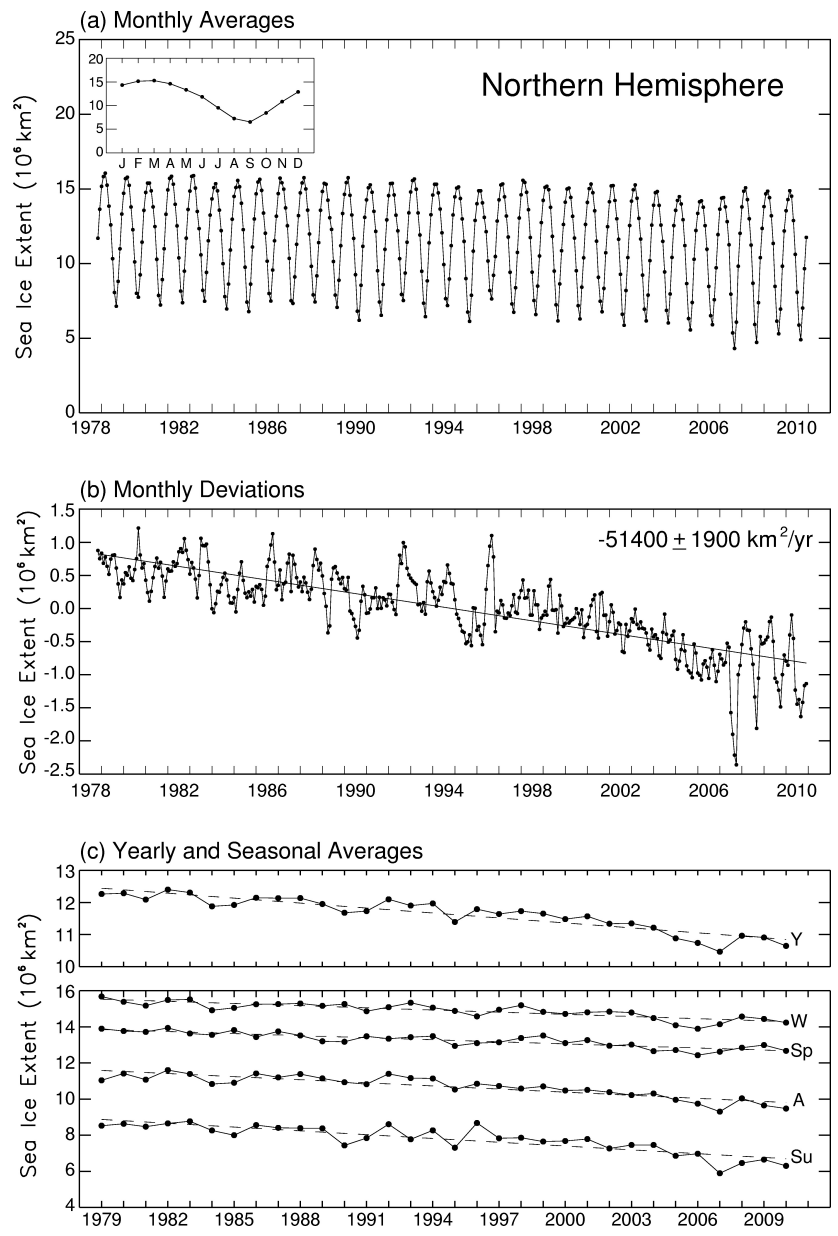

Fig. 2. (a) Monthly averaged Northern Hemisphere sea ice extents for November 1978 through December 2010. The inset shows the average annual cycle. (b) Monthly deviations for the sea ice extents. (c) Yearly and seasonally averaged sea ice extents for the years 1979-2010. The winter (W), spring (Sp), summer (Su), and autumn (A) values cover the periods January-March, April-June, July-September, and October-December, respectively.

winter has increased by $1 \%$, but for spring, it has decreased by $4 \%$.

While the Northern Hemisphere yearly trend of $-51.5 \pm 4.1 \times 10^{3} \mathrm{~km}^{2} \mathrm{yr}^{-1}$ for the 32-yr period (19792010) (Table 1) is $14 \%$ more negative than the corresponding trend of $-45.1 \pm 4.6 \mathrm{~km}^{2} \mathrm{yr}^{-1}$ for the 28 -yr period (19792006) reported by Parkinson and Cavalieri (2008), the changes from the 28 -yr period to the $32-\mathrm{yr}$ period on a regional basis were far from uniform.

\subsubsection{Regional}

Figure 3 shows the sea ice extent monthly deviations and their trends for each of the nine Arctic regions and for the hemisphere as a whole. Examination of the figure illustrates the very large differences in regional sea ice 
Table 1. Yearly and seasonal Arctic sea ice extent trends for the period 1979-2010 with estimated standard deviations* .

\begin{tabular}{|c|c|c|c|c|c|c|c|c|c|c|c|c|c|c|c|}
\hline \multirow[t]{2}{*}{ Region } & \multicolumn{3}{|c|}{ Yearly } & \multicolumn{3}{|c|}{ Winter } & \multicolumn{3}{|c|}{ Spring } & \multicolumn{3}{|c|}{ Summer } & \multicolumn{3}{|c|}{ Autumn } \\
\hline & $10^{3} \mathrm{~km}^{2} \mathrm{yr}^{-1}$ & $R$ & $\%$ decade $^{-1}$ & $10^{3} \mathrm{~km}^{2} \mathrm{yr}^{-1}$ & $R$ & $\%$ decade $^{-1}$ & $10^{3} \mathrm{~km}^{2} \mathrm{yr}^{-1}$ & $R$ & $\%$ decade $^{-1}$ & $10^{3} \mathrm{~km}^{2} \mathrm{yr}^{-1}$ & $R$ & $\%$ decade $^{-1}$ & $10^{3} \mathrm{~km}^{2} \mathrm{yr}^{-1}$ & $R$ & $\%$ decade $^{-1}$ \\
\hline $\mathrm{NH}$ & $-51.5 \pm 4.1$ & 41 & $-4.1 \pm 0.3$ & $-40.0 \pm 4.4$ & 00 & $-2.6 \pm 0.3$ & $-38.1 \pm 3.7$ & .22 & $-2.8 \pm 0.3$ & $-70.1 \pm 7.8$ & 8.99 & $-7.9 \pm 0.9$ & $3 \pm 5.7$ & 10.09 & 0.5 \\
\hline Okhotsk : & & & & & & & & & & NI & - & - & & 2.15 & \\
\hline & & & & & & & & 0.38 & & \pm 0.0 & - & & & 1.71 & \\
\hline Hudsc & $-4.4 \pm 0.7$ & 5.97 & 9 & $.0 \pm 0.0$ & 1.14 & $-0.0 \pm$ & $-3.1 \pm 0.7$ & 4.49 & $-2.6 \pm 0.6$ & $-5.7 \pm 1.2$ & 4.84 & $-19.1 \pm 3.9$ & -8 & 5.41 & $-12.9 \pm 2.4$ \\
\hline & & 466 & & & 2.97 & & & 4.00 & & \pm 1.1 & 4.79 & & & 5.23 & \\
\hline Gulf & $-0.5 \pm 0.3$ & 1.67 & .5 & $9 \pm 0.8$ & 2.22 & $-8.6 \pm$ & $-0.3 \pm 0.3$ & 1.03 & -4.3 & NI & - & - & $0.2 \pm 0.1$ & 2.04 & $6.9 \pm 3.4$ \\
\hline & & 5.77 & & & 5.09 & & & 4.96 & & $-4.8 \pm 1.6$ & 3.01 & & & 4.10 & $=2.0$ \\
\hline Kara and Barents Seas & $-13.5 \pm 2.3$ & 5.80 & $-9.2 \pm$ & $-12.2 \pm 2.4$ & 4.98 & $-6.3=$ & $-14.0 \pm 3.2$ & 4.44 & -7.7 & $-13.8 \pm 2.8$ & 4.86 & $-18.4 \pm 3.8$ & $-13.8 \pm 2.7$ & 5.08 & $-10.2 \pm 2.0$ \\
\hline Arct & & 6.33 & & & 1.34 & & & 3.30 & & $-38.4 \pm 6.1$ & 6.25 & & $-17.4 \pm 2.9$ & 5.93 & -2 \\
\hline Canadian Archipelago & $-0.9 \pm 0.4$ & 2.53 & $-1.3 \pm 0.5$ & $-0.0 \pm 0.0$ & 1.10 & $-0.0 \pm 0.0$ & $-0.4 \pm 0.1$ & 2.59 & $-0.5 \pm 0.2$ & $-2.2 \pm 1.1$ & 2.05 & $-3.9 \pm 1.9$ & $-1.1 \pm 0.4$ & 3.10 & $-1.5 \pm 0.5$ \\
\hline
\end{tabular}

* Each is given as $10^{3} \mathrm{~km}^{2} \mathrm{yr}^{-1}$ and $\%$ decade ${ }^{-1} . R$ is the ratio of the absolute value of the trend to its standard deviation. Assuming a null hypothesis of zero trend and 30 degrees of freedom, R-values in bold indicate a statistical significance of $95 \%$; values in italicized bold indicate a significance level of $99 \%$. NI means no ice.
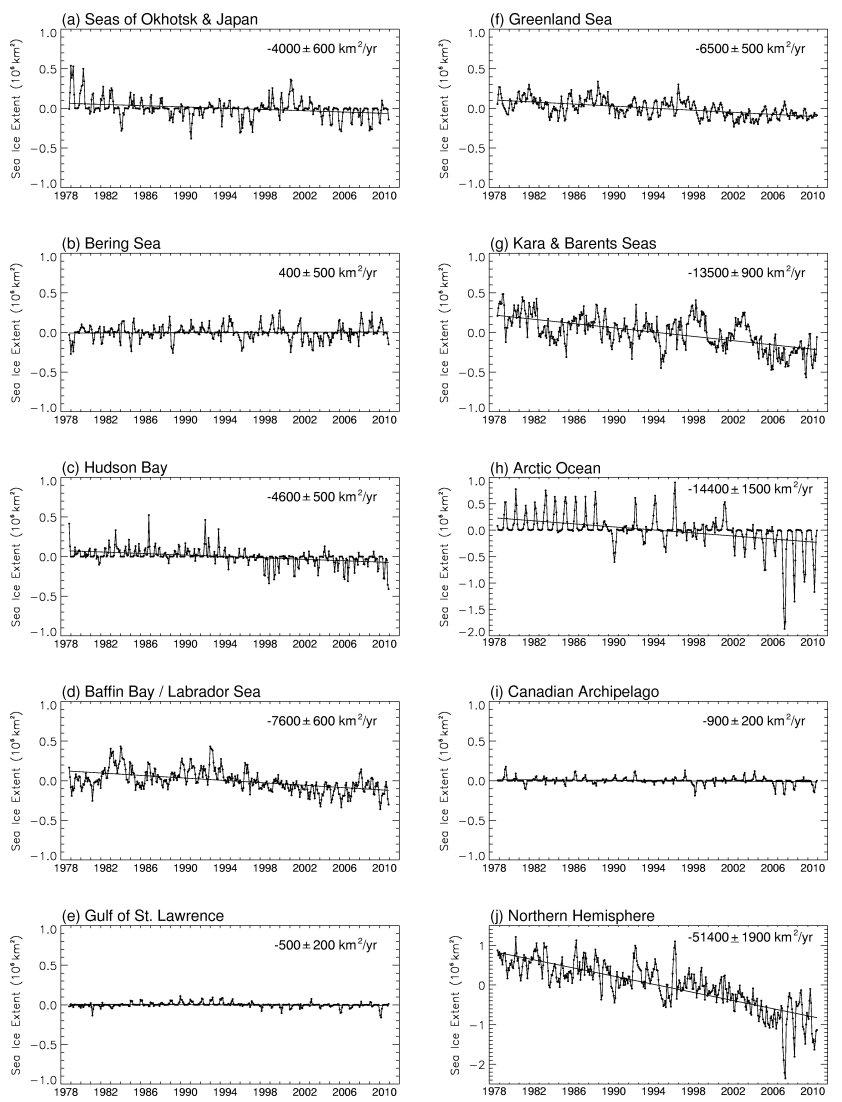

Fig. 3. Monthly deviations of the sea ice extents for (a) Seas of Okhotsk and Japan, (b) Bering Sea, (c) Hudson Bay, (d) Baffin Bay/Labrador Sea, (e) Gulf of St. Lawrence, (f) Greenland Sea, (g) Kara and Barents Seas, (h) Arctic Ocean, (i) Canadian Archipelago, and (j) Northern Hemisphere.

extent variabilities over the $32-y r$ period. The three regions contributing most to the overall negative trend of the Northern Hemisphere are the Arctic Ocean $(-14.4 \pm 1.5 \times$ $\left.10^{3} \mathrm{~km}^{2} \mathrm{yr}^{-1}\right)$, the Kara and Barents Seas $(-13.5 \pm 0.9 \times$ $\left.10^{3} \mathrm{~km}^{2} \mathrm{yr}^{-1}\right)$, and the Baffin Bay/Labrador Sea region $\left(-7.6 \pm 0.6 \times 10^{3} \mathrm{~km}^{2} \mathrm{yr}^{-1}\right)$ (Fig. 3). These three regions account for over half of the total area of the nine Arctic regions combined.
The yearly trends for the Arctic Ocean and Kara and Barents Seas regions (Table 1) represent increases of $45 \%$ and $27 \%$ in the magnitude of the negative yearly trends, respectively, compared with the corresponding yearly trends for the 28-yr period (1979-2006) reported by Parkinson and Cavalieri (2008). Other regions showing more negative trends for the longer period are the Seas of Okhotsk and Japan, the Gulf of St. Lawrence, and the Canadian Archipelago.

Some regions had less negative yearly trends for the 32-yr period compared to the 28-yr period. These included Hudson Bay, Baffin Bay/Labrador Sea, and the Greenland Sea regions (Table 1 versus Parkinson and Cavalieri, 2008). In contrast to the other eight regions, the Bering Sea had a positive trend $\left(+0.3 \pm 0.8 \times 10^{3} \mathrm{~km}^{2} \mathrm{yr}^{-1}\right)$ for the 32 -yr period, although not statistically significant (Table 1). For the 28-yr period, the Bering Sea trend was $-0.5 \pm 1.0 \times 10^{3} \mathrm{~km}^{2} \mathrm{yr}^{-1}$ (Parkinson and Cavalieri, 2008).

\subsubsection{Sea ice extent trends by month for all regions}

Figure 4 shows the sea ice extent trends by month for the 32yr period 1979-2010 for each of the nine Arctic regions and for the Northern Hemisphere as a whole. Most of the nine regions show either zero or negative trends for each of the 12 months. Only the Bering Sea and the Gulf of St. Lawrence show positive trends for some months. By far the largest regional negative trend occurs for the Arctic Ocean region in the month of September (Fig. 4h). The Seas of Okhotsk and Japan and the Gulf of St. Lawrence are completely free of ice during July, August, and September, whereas the Bering Sea is totally ice free only in August.

The Northern Hemisphere (Fig. 4j) shows an interesting seasonal pattern in the monthly trends. From September through May, the trends become less negative, reaching a minimum trend magnitude in May, whereas from May through September the monthly trends become more negative. The Northern Hemisphere September trend almost reaches $-80 \times 10^{3} \mathrm{~km}^{2} \mathrm{yr}^{-1}$. The September trends for most of the individual regions are zero or close to zero. However, the Arctic Ocean and the Canadian Archipelago regions have their most negative trend in September. These two regions have zero trends for the winter months as a result of being 


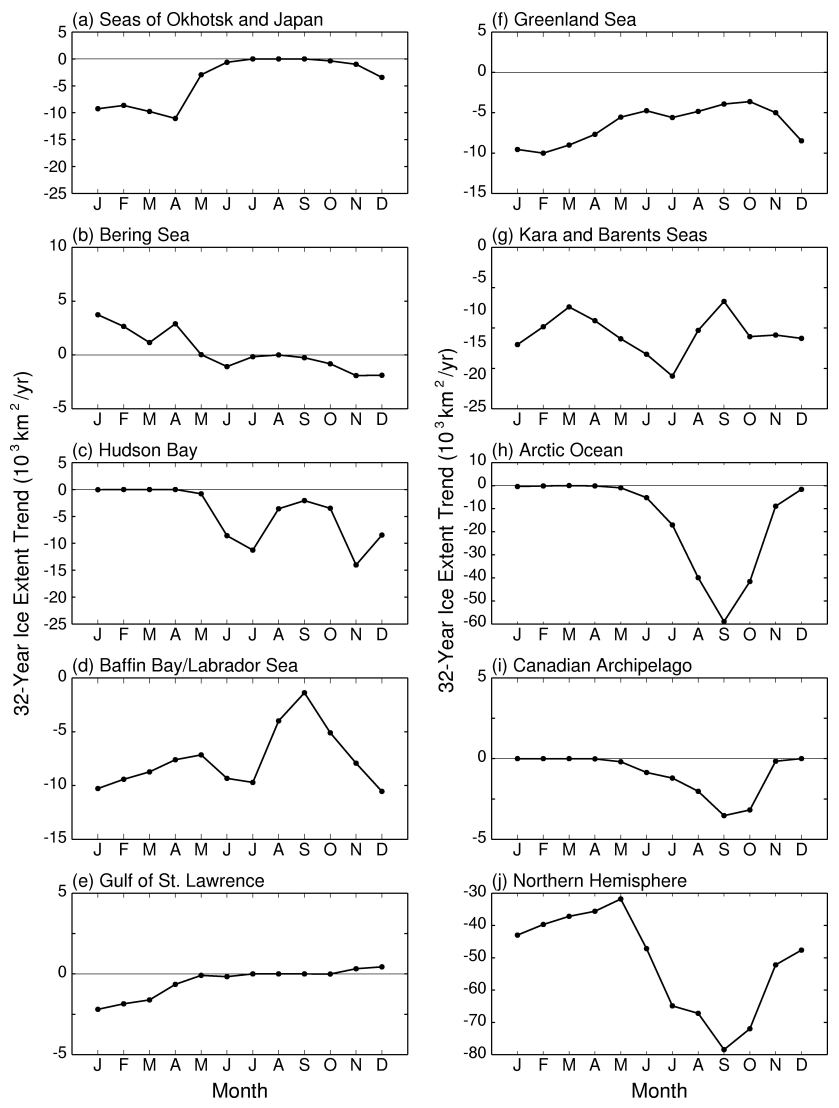

Fig. 4. Sea ice extent trends by month over the 32-yr period 19792010 for (a) Seas of Okhotsk and Japan, (b) Bering Sea, (c) Hudson Bay, (d) Baffin Bay/Labrador Sea, (e) Gulf of St. Lawrence, (f) Greenland Sea, (g) Kara and Barents Seas, (h) Arctic Ocean, (i) Canadian Archipelago, and (j) Northern Hemisphere.

completely covered by sea ice of at least $15 \%$ ice concentration in all winters of the 1979-2010 period.

A comparison of Fig. 12 in Parkinson and Cavalieri (2008) with our Fig. 4 shows that the Bering Sea had positive trends only for the months of January and February for the 1979-2006 period, in contrast to the four months of positive trends for the 32-yr period (Fig. 4b). For the Northern Hemisphere as a whole, the largest negative trend occurs in September for both the 28-yr and the 32-yr periods, but for the 28 -yr period the September negative trend was approximately $-57 \times 10^{3} \mathrm{~km}^{2} \mathrm{yr}^{-1}$, versus the much higher magnitude $-80 \times 10^{3} \mathrm{~km}^{2} \mathrm{yr}^{-1}$ trend for the 32 -yr period.

\subsection{Sea ice areas}

Sea ice areas are defined as the cumulative sum of the product of the grid cell ice concentration and grid cell area for all grid cells having at least $15 \%$ ice concentration. Sea ice extents are usually greater (and never less) than sea ice areas, but the two are equal for the case where all ice concentrations are $100 \%$. We first examine the variabilities and trends for the Northern Hemisphere as a whole and then for each of the nine Arctic regions.

\subsubsection{Northern Hemisphere total}

Similar to Fig. 2a for sea ice extents, Fig. 5a shows the monthly average sea ice areas for the total Northern Hemisphere as well as the average seasonal cycle (Fig. 5a inset) based on monthly averages. Overall, the month of maximum sea ice area is March, closely followed by February. The month of minimum sea ice area is September. The year with the largest March sea ice area for the Northern Hemisphere is 1979 , having an area of 14.2 million square kilometers, whereas the year with the smallest September sea ice area (3.1 million square kilometers) is 2007. The hemispheric yearly trend of $-49.6 \pm 4.0 \times 10^{3} \mathrm{~km}^{2} \mathrm{yr}^{-1}$ for the 32 -yr period (Table 2) is $21 \%$ more negative than the corresponding trend of $-41.0 \pm 4.3 \times 10^{3} \mathrm{~km}^{2} \mathrm{yr}^{-1}$ for the 28 -yr period (1979-2006) reported by Parkinson and Cavalieri (2008).

Figure $5 \mathrm{~b}$ shows sea ice area monthly deviations with an overall trend of $-49.3 \pm 1.9 \times 10^{3} \mathrm{~km}^{2} \mathrm{yr}^{-1}$, and the year-toyear variability is almost identical to that for the sea ice extents. Likewise, the sea ice area yearly and seasonal averages shown in Fig. 5c are similar to the corresponding plots for sea ice extent, although all the values are reduced. The 19792010 seasonal trends are more negative for each season (Table 2) than the 1979-2006 trends (Parkinson and Cavalieri, 2008). We next examine the changes in trends by region. As with the sea ice extents, the changes from the 28-yr period to the 32-yr period were far from uniform.

\subsubsection{Regional}

Regionally and seasonally, the sea ice area variabilities are somewhat different than those for sea ice extents, reflecting the influence of sea ice concentration variability. The sea ice area trends are sometimes smaller than the corresponding sea ice extent trends, sometimes larger, and sometimes of opposite sign.

Figure 6 shows the sea ice area monthly deviations and their trends for each of the nine Arctic regions and for the hemisphere as a whole. As with the sea ice extent trends, the three regions contributing most to the overall negative sea ice area trend of the Northern Hemisphere are the Arctic Ocean $\left(-18.4 \pm 1.6 \times 10^{3} \mathrm{~km}^{2} \mathrm{yr}^{-1}\right)$, the Kara and Barents Seas $\left(-12.3 \pm 0.8 \times 10^{3} \mathrm{~km}^{2} \mathrm{yr}^{-1}\right)$, and the Baffin Bay/Labrador Sea region $\left(-5.9 \pm 0.6 \times 10^{3} \mathrm{~km}^{2} \mathrm{yr}^{-1}\right)$.

When examined on a yearly average basis (Table 2), the trends for the Arctic Ocean and Kara and Barents Seas regions represent increases in magnitude (more negative) of $63 \%$ and $27 \%$, respectively, compared with the corresponding trends for the 28-yr period (1979-2006) reported by Parkinson and Cavalieri (2008). Other regions showing more negative trends for the longer period are the Gulf of St. Lawrence and the Canadian Archipelago. 
Table 2. Yearly and seasonal Arctic sea ice area trends for the period 1979-2010 with estimated standard deviations*.

\begin{tabular}{|c|c|c|c|c|c|c|c|c|c|c|c|c|c|c|c|}
\hline \multirow[t]{2}{*}{ Region } & \multicolumn{3}{|c|}{ Yearly } & \multicolumn{3}{|c|}{ Winter } & \multicolumn{3}{|c|}{ Spring } & \multicolumn{3}{|c|}{ Summer } & \multicolumn{3}{|c|}{ Autumn } \\
\hline & $10^{3} \mathrm{~km}^{2} \mathrm{yr}^{-1}$ & $R$ & $\%$ decade $^{-1}$ & $10^{3} \mathrm{~km}^{2} \mathrm{yr}^{-1}$ & $R$ & $\%$ decade $^{-1}$ & $10^{3} \mathrm{~km}^{2} \mathrm{yr}^{-1}$ & $R$ & $\%$ decade $^{-1}$ & $10^{3} \mathrm{~km}^{2} \mathrm{yr}^{-1}$ & $R$ & $\%$ decade $^{-1}$ & $10^{3} \mathrm{~km}^{2} \mathrm{yr}^{-1}$ & $R$ & $\%$ decade $^{-1}$ \\
\hline $\mathrm{NH}$ & \pm 4.0 & 12.27 & $-4.6 \pm 0.4$ & $1.0 \pm 4.6$ & 6.7 & $-2.2 \pm 0.3$ & $42.4 \pm 4.2$ & 10.00 & 3 & $8 \pm 6.4$ & 0.97 & $=0.9$ & $-54.7 \pm 6.4$ & 8.61 & .6 \\
\hline Okho & & 3.60 & & & 3. & & & 2.67 & & NI & - & - & & 2.35 & \\
\hline & & & & & 1.48 & & & 0.61 & & $-0.1 \pm 0.0$ & - & $-29.1 \pm 2.5$ & & 1.20 & \\
\hline Hud: & $-4.0 \pm 0.7$ & 5.47 & $-5.6 \pm 1.0$ & $-0.7 \pm 0.3$ & 2.4 & $-0.6 \pm 0.2$ & $-5.2 \pm 1.1$ & 4.62 & $-5.0 \pm 1.1$ & $-2.6 \pm 0.6$ & 4.12 & -19 & 1.5 & 4.78 & $-14.3 \pm 3.0$ \\
\hline Baff & & 4.42 & & & 2. & & & 4. & & & 4.96 & \pm 3.9 & & 4.75 & -12.2 \\
\hline Gulf & $-0.5 \pm 0.2$ & 2.40 & $-10.4 \pm 4.3$ & $-1.7 \pm 0.6$ & 2.61 & $-12.6 \pm 4.8$ & $-0.3 \pm 0.1$ & 1.77 & $-8.2 \pm 4.6$ & NI & - & - & $0.1 \pm 0.0$ & 1.21 & $3.3 \pm 2.8$ \\
\hline & & 4.30 & & & 3.63 & & & 4.10 & & \pm 1.1 & 2.08 & 4.4 & & 2.81 & $-6.8 \pm 2.4$ \\
\hline Kara and Barents Seas & $-12.2 \pm 2.1$ & 5.83 & $-10.3 \pm 1.8$ & $-12.6 \pm 2.7$ & 4.73 & $-7.5 \pm 1.6$ & $-14.9 \pm 3.0$ & 5.02 & $-9.7=$ & $-9.2 \pm 2.1$ & 4.43 & $-20.4 \pm 4.6$ & $-12.3 \pm 2.6$ & 4.75 & $-11.3 \pm 2.4$ \\
\hline & & 7.34 & & & 3.71 & & & 4.29 & & -49 & 8.87 & $-9.1 \pm 1.0$ & -21 . & 5.42 & $-3.3 \pm 0.6$ \\
\hline Canadian Archipelago & $-1.4 \pm 0.4$ & 3.27 & $-2.3 \pm 0.7$ & $0.7 \pm 0.1$ & 5.31 & $1.0 \pm 0.2$ & $-1.0 \pm 0.3$ & 3.11 & $-1.4 \pm 0.4$ & $-3.4 \pm 1.0$ & 3.34 & $-8.6 \pm 2.6$ & $-1.9 \pm 0.5$ & 3.50 & $-2.8 \pm 0.8$ \\
\hline
\end{tabular}

* Each is given as $10^{3} \mathrm{~km}^{2} \mathrm{yr}^{-1}$ and \% decade ${ }^{-1} . R$ is the ratio of the absolute value of the trend to its standard deviation. Assuming a null hypothesis of zero trend and 30 degrees of freedom, R-values in bold indicate a statistical significance of $95 \%$; values in italicized bold indicate a significance level of $99 \%$. NI means no ice.

Some regions had less negative trends for the 32-yr period compared to the 28-yr period. These included the Seas of Okhotsk and Japan, Hudson Bay, Baffin Bay/Labrador Sea, and the Greenland Sea regions. As with sea ice extent and in contrast to the other eight regions, the Bering Sea had a positive trend $\left(+0.5 \pm 0.6 \times 10^{3} \mathrm{~km}^{2} \mathrm{yr}^{-1}\right)$ for the 32 -yr period. For the $28-\mathrm{yr}$ period, the Bering Sea trend was negative $\left(-0.2 \pm 0.7 \times 10^{3} \mathrm{~km}^{2} \mathrm{yr}^{-1}\right)$.

\subsubsection{Sea ice area trends by month for all regions}

Figure 7 shows the sea ice area trends by month for each of the nine Arctic regions and for the Northern Hemisphere as a whole. While the seasonal patterns for the Northern Hemisphere and for each of the Arctic regions generally match those for the sea ice extents, there are two important differences. First, for the Northern Hemisphere, the smallest sea ice area trend occurs in March (Fig. 7j), whereas for sea ice extent the smallest trend occurred in May (Fig. 4j). As with sea ice extent, the largest negative trend occurs in September, although the magnitude of the ice area trend for October is almost as large, in contrast to the sea ice extent October value (Fig. 4j).

The second difference between the sea ice extent and area trends by month is that during the months of January through April the sea ice area trends are slightly positive for the Arctic Ocean and the Canadian Archipelago regions in contrast to the zero sea ice extent trends for the same months and regions. This implies that the sea ice concentration has been increasing over at least portions of these regions. These Arctic Ocean and the Canadian Archipelago ice area trends are somewhat less than the positive trends found by Parkinson and Cavalieri (2008) for the 28-yr period. These two regions are the only ones with statistically significant positive sea ice area trends for the winter season as a whole, although the Bering Sea has a statistically insignificant positive trend (Table 2).

For the 28-yr period (Parkinson and Cavalieri, 2008), the Bering Sea had positive trends in ice areas and ice extents only for the months of January and February, whereas for the 32-yr period, the ice areas and ice extents had positive trends from January through April (Figs. 4 and 7). Also,
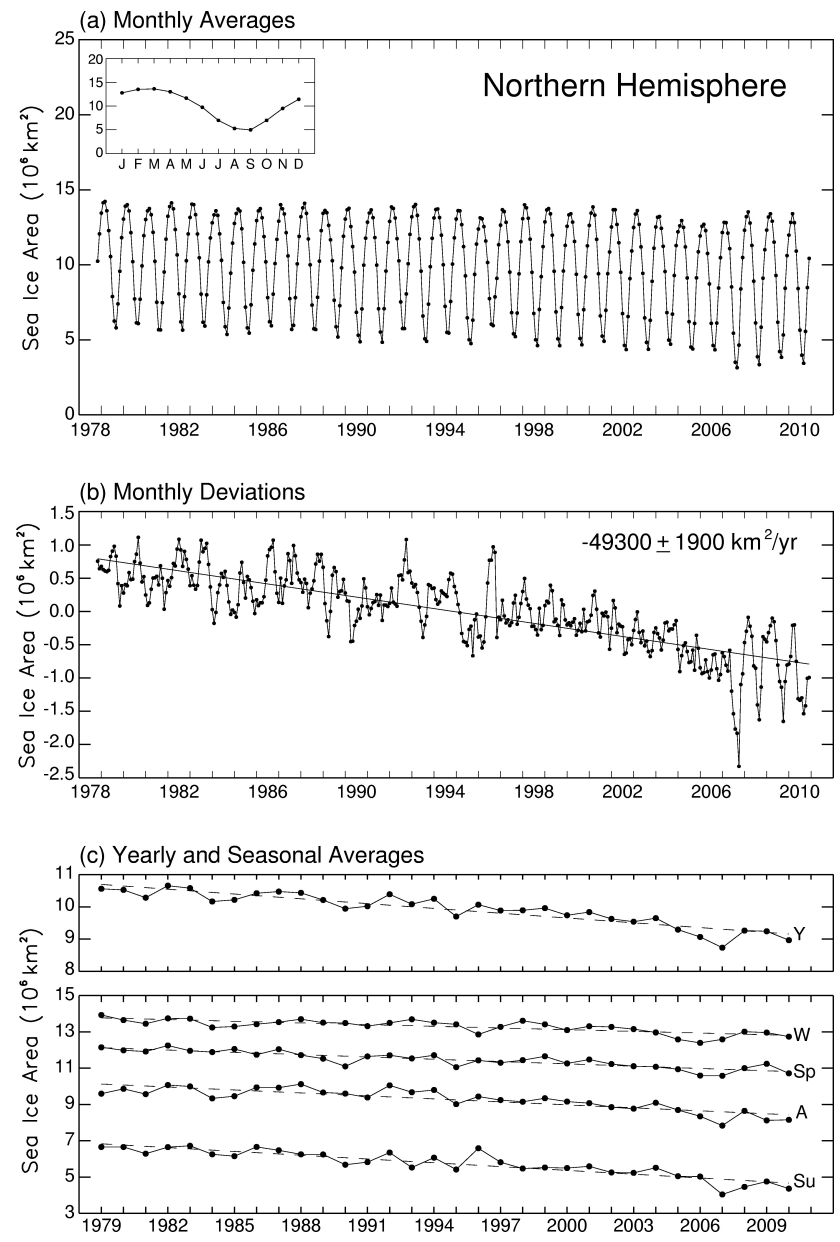

Fig. 5. (a) Monthly averaged Northern Hemisphere sea ice areas for November 1978 through December 2010. The inset shows the average annual cycle. (b) Monthly deviations for the sea ice areas. (c) Yearly and seasonally averaged sea ice areas for the years 1979-2010. The winter (W), spring (Sp), summer (Su), and autumn (A) values cover the periods January-March, April-June, JulySeptember, and October-December, respectively.

for the entire Northern Hemisphere, the maximum negative ice-area trends for the 28-yr period were between 50$55 \times 10^{3} \mathrm{~km}^{2} \mathrm{yr}^{-1}$ for the months of June, July, August, and 

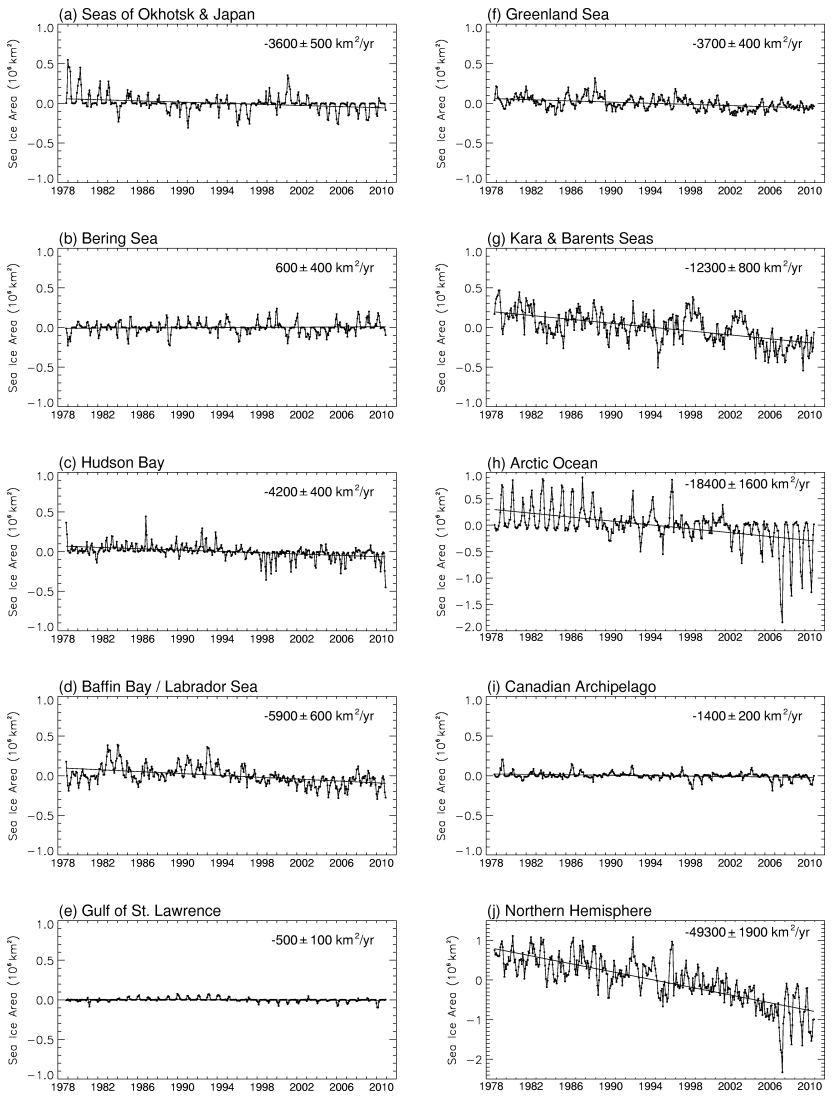

Fig. 6. Monthly deviations of the sea ice areas for (a) Seas of Okhotsk and Japan, (b) Bering Sea, (c) Hudson Bay, (d) Baffin Bay/Labrador Sea, (e) Gulf of St. Lawrence, (f) Greenland Sea, (g) Kara and Barents Seas, (h) Arctic Ocean, (i) Canadian Archipelago, and (j) Northern Hemisphere.

September, whereas for the 32-yr period, the maximum negative ice-area trend for the month of September was almost $-75 \times 10^{3} \mathrm{~km}^{2} \mathrm{yr}^{-1}$.

\section{Trend comparisons through 1996, 2006, and 2010}

The decline of the Arctic sea ice cover has accelerated overall in recent years, but this has occurred with significant differences in regional and seasonal trends. For the Northern Hemisphere as a whole, there was a $14 \%$ more negative trend in yearly average sea ice extent over the 32-yr period 1979 2010 than for the previously analyzed 28-yr period (Parkinson and Cavalieri, 2008). Seasonally, the Northern Hemisphere sea ice extent trend became more negative by $31 \%$ for summer and by $20 \%$ for autumn. Regionally, the largest percent change occurred for the Bering Sea, which changed from a small negative trend to a small positive trend in the yearly average, but neither trend was statistically significant. Hudson Bay, Baffin Bay/Labrador Sea, and the Greenland Sea regions had somewhat smaller negative yearly average trends for the 32-yr period, whereas the Seas of Okhotsk and
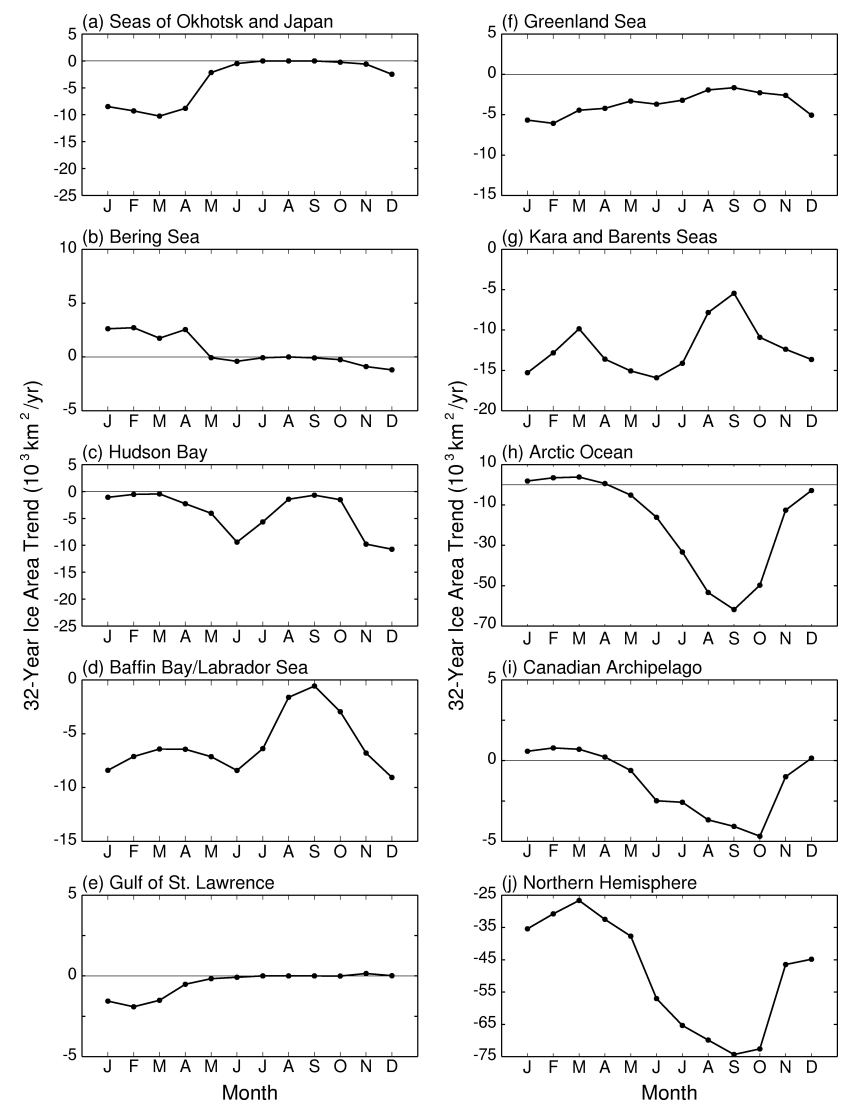

Fig. 7. Sea ice area trends by month over the 32-yr period 19792010 for (a) Seas of Okhotsk and Japan, (b) Bering Sea, (c) Hudson Bay, (d) Baffin Bay/Labrador Sea, (e) Gulf of St. Lawrence, (f) Greenland Sea, (g) Kara and Barents Seas, (h) Arctic Ocean, (i) Canadian Archipelago, and (j) Northern Hemisphere.

Japan had a slightly greater negative trend. In contrast, the regions of the Gulf of St. Lawrence, the Kara and Barents Seas, the Arctic Ocean, and the Canadian Archipelago all had considerably larger negative yearly average trends over 32 yr than they had for the 28-yr period.

To compare also with the earlier Parkinson et al. (1999) study for the 1979-1996 period as well as the Parkinson and Cavalieri (2008) study for the 1979-2008 period, Tables 3 and 4 summarize sea ice extent and area trends, respectively, for each of the three study periods: 1979-1996 (period 1), 1979-2006 (period 2), and 1979-2010 (period 3). On a yearly basis and for the summer and autumn seasons, there was an increasingly negative trend for sea ice extents from period 1 to period 3 for the Northern Hemisphere (Table 3). For winter there was also a substantial increase in magnitude of the negative trend from period 1 to period 2 but only a slightly more negative trend for period 3 than for period 2 . In contrast, for spring, there was a slight decrease in negative trends going from period 1 to period 3 .

For the 9 regions individually, there was a complex array of changing trends both by region and season (Table 3 ). 
Table 3. Yearly and seasonal Arctic sea ice extent trends with estimated standard deviations $\left(10^{3} \mathrm{~km}^{2} \mathrm{yr}^{-1}\right)$ for each of three periods: $1979-$ 1996 (1), 1979-2006 (2), and 1979-2010 (3). NI means no ice. Values for 1979-1996 are from Parkinson et al. (1999); values for 1979-2006 are from Parkinson and Cavalieri (2008); and values for 1979-2010 are from Table 1 above.

\begin{tabular}{|c|c|c|c|c|c|c|c|c|c|c|c|c|c|c|c|}
\hline \multirow{2}{*}{$\begin{array}{l}\text { Yearly/Seasonal } \\
\text { Region/Period }\end{array}$} & \multicolumn{3}{|c|}{ Yearly } & \multicolumn{3}{|c|}{ Winter } & \multicolumn{3}{|c|}{ Spring } & \multicolumn{3}{|c|}{ Summer } & \multicolumn{3}{|c|}{ Autumn } \\
\hline & 1 & 2 & 31 & 1 & 2 & 3 & 1 & 2 & 3 & 1 & 2 & 31 & 1 & 2 & \\
\hline $\mathrm{NH}$ & - & & 1 & 9.2 & 6 & 1.4 & - & 4.6 & 3.7 & 7.6 & 7.9 & $=7.8$ & 1.9 & & \\
\hline sk and Japan & & & & & & & & & & & & NI & 1.9 & & \\
\hline & & 1.0 & & & & & & 1.9 & & 0.0 & & $=0.0$ & & 1.1 & \pm 0.9 \\
\hline & & & & & & & & & & & & & & & $-8.6 \pm 1.6$ \\
\hline B & & & & & & & & & & & & \pm 1.1 & & $-8.5 \pm 1.8$ & $-7.9 \pm 1.5$ \\
\hline & & & & & & & & & & & & & & 0.2 & $0.2 \pm 0.1$ \\
\hline & S & & & & & & & & & & & \pm 1.6 & & & \\
\hline $\mathrm{K}$ & -1 & & & & & & $-25.9 \pm$ & & & & & & & 3.0 & -13 \\
\hline & & & & & & & & & & -23.2 & & & & $-12.4 \pm 2.7$ & $-17.4 \pm$ \\
\hline Canadian Archipelago & $-0.6 \pm 0.7$ & $-0.5 \pm 0.4$ & $-0.9 \pm 0.4$ & $-0.0 \pm 0.0$ & $-0.0 \pm 0.0$ & $-0.0 \pm 0.0$ & $-0.5 \pm 0.3$ & $-0.3 \pm 0.2$ & $-0.4 \pm 0.1$ & $-1.4 \pm 2.2$ & $-0.8 \pm 1.2$ & $-2.2 \pm 1.1$ & $-0.3 \pm 0.6$ & $-0.9 \pm 0.4$ & $-1.1 \pm 0.4$ \\
\hline
\end{tabular}

Table 4. Yearly and seasonal Arctic sea ice area trends with estimated standard deviations $\left(10^{3} \mathrm{~km}^{2} \mathrm{yr}^{-1}\right)$ for each of three periods: $1979-$ 1996 (1), 1979-2006 (2), and 1979-2010 (3). NI means no ice. Values for 1979-1996 are from Parkinson et al. (1999); values for 1979-2006 are from Parkinson and Cavalieri (2008); and values for 1979-2010 are from Table 2 above.

\begin{tabular}{|c|c|c|c|c|c|c|c|c|c|c|c|c|c|c|c|}
\hline \multirow{2}{*}{$\begin{array}{l}\text { Yearly/Seasonal } \\
\text { Region/Period }\end{array}$} & \multicolumn{3}{|c|}{ Yearly } & \multicolumn{3}{|c|}{ Winter } & \multicolumn{3}{|c|}{ Spring } & \multicolumn{3}{|c|}{ Summer } & \multicolumn{3}{|c|}{ Autumn } \\
\hline & 1 & 2 & 3 & 1 & 2 & 31 & 1 & 2 & 3 & 1 & 2 & 3 & 1 & 2 & \\
\hline $\mathrm{NH}$ & $3 \pm 8.3$ & \pm 4.3 & 4.0 & $1.4 \pm 9.6$ & $9.0 \pm 5.7$ & $-31.0 \pm 4.6$ & \pm 9.6 & 4.9 & 4.2 & 14.9 & & 6.4 & 3.2 & & 17 \\
\hline & & & & & & & & & & & & II & & & \\
\hline & & & & & .9 & & 2.6 & .3 & 1.1 & -0.1 & 0.0 & & & & \\
\hline & & & .7 & & -0 & & 1.5 & & & & & & 3.6 & 1.9 & $-7.3 \pm 1.5$ \\
\hline & & & & & & & & & & & & $=0.6$ & & & $-6.3 \pm 1.3$ \\
\hline & & & & & & & & & & & & NI & & & \\
\hline & 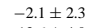 & $-4.2=$ & $-3.7=$ & & -5 & & $-1.3 \pm 2.1$ & & & -0.4 & & $=1.1$ & 0.4 & 1.5 & $-3.3 \pm 1.2$ \\
\hline $\mathrm{Ka}$ & & $-9.6=$ & & & & & & & & & & & & 2.9 & \\
\hline & & & & & & & - & & & -2 & -3 & & -5 & 3.7 & -21 \\
\hline Canadian Archipelago & $-1.2 \pm 0.9$ & $-1.1 \pm 0.5$ & $-1.4 \pm 0.4$ & $1.3 \pm 0.3$ & \pm 0.2 & $7 \pm 0.1$ & $-1.9 \pm 0.6$ & \pm 0.4 & $-1.0 \pm 0.3$ & $-3.6 \pm 2.4$ & $-2.7 \pm 1.3$ & $-3.4 \pm 1.0$ & $-0.6 \pm 0.9$ & $-1.5 \pm 0.7$ & $-1.9 \pm 0.5$ \\
\hline
\end{tabular}

Baffin Bay/Labrador Sea and the Gulf of St. Lawrence went from positive yearly trends for period 1 to negative trends for period 2 and maintained negative trends for period 3, whereas the Bering Sea went from a slight positive trend for period 1 to a slight negative trend for period 2 and then back to a slight positive trend for period 3. All other regions had negative yearly trends for each of the three periods, with some increasing and others decreasing in magnitude from period 1 to period 2 and from period 2 to period 3 (Table 3 ).

Hudson Bay, Baffin Bay/Labrador Sea, and the Gulf of St. Lawrence all showed a similar pattern of positive to negative trends from period 1 to period 2 or more negative trends for period 2 than for period 1 for all four seasons except winter for Hudson Bay (which continues to have full ice coverage each winter) and summer for the Gulf of St. Lawrence (which has essentially no ice in the summer) (Table 3). This was followed by mostly small changes in trend from period 2 to period 3. By contrast, the Seas of Okhotsk and Japan instead showed a sharp decrease in negative trends from period 1 to period 2 for winter, spring, autumn, and the yearly averages and lesser trend changes (in both directions) from period 2 to period 3 (Table 3). The largest change for the Arctic Ocean came with the dramatic increase in summertime trend from period 2 to period 3, whereas for the Kara and Barents Seas, the spring shift from period 1 to period 2 was the strongest (Table 3).

The sea ice area trends shown in Table 4 generally follow the patterns for the sea ice extent trends shown in Table 3. Two prominent exceptions are the Arctic Ocean and Hudson Bay regions. The Arctic Ocean has winter sea ice extent trends of near zero for each period, reflective of the fact that the Arctic Ocean region is almost completely filled with sea ice of concentrations of at least $15 \%$ in each year of the record. The winter sea ice area trends, in contrast, are 7.3, 4.2 , and $3.0 \times 10^{3} \mathrm{~km}^{2} \mathrm{yr}^{-1}$ for periods 1,2 , and 3 , respectively. For all three periods, the positive sea ice area trends indicate an overall increase from 1979 in sea ice concentrations in at least some areas of the Arctic Ocean region, although this overall increase has decreased. In winter, Hudson Bay is filled with sea ice having concentrations of at least $15 \%$, thus has zero sea ice extent trends for all three periods (Table 3 ), whereas the sea ice area trends are $0.8,-0.6$, and $-0.7 \times 10^{3} \mathrm{~km}^{2} \mathrm{yr}^{-1}$ for periods 1,2 , and 3 , respectively, showing that, unlike the situation in the Arctic Ocean, the sea ice concentrations in Hudson Bay decreased overall in the periods 1979-2006 and 1979-2010.

\section{Conclusions}

The regional, seasonal, and even monthly sea ice trend variabilities presented here for the period 1979-2010 reflect the highly complex nature of the Arctic climate system. Comparison of the trends for this 32-yr period with those for the shorter time series illustrates that the addition of four years shows the continued acceleration of the Northern Hemisphere sea ice cover, particularly during summer. A recent review of the Arctic's decreasing sea ice cover by Stroeve et al. (2012) for the same period covered in this study, 19792010, also shows the acceleration in the decline of the Arctic sea ice cover and further synthesizes the relevant sea ice forcing mechanisms, including increasing Arctic air temperatures, atmospheric and oceanic circulation changes, and the 
changing concentrations of greenhouse gases as well as the important ice-albedo feedback mechanism. The reader is referred to the Stroeve et al. (2012) paper for an excellent review of the ice/ocean/atmosphere connections relevant to the sea ice changes over the 1979-2010 period.

In addition to examining the Northern Hemisphere as a whole, as in Stroeve et al. (2012), the current study documents several key findings for nine regions and all four seasons over the 32-yr period. The Arctic Ocean region showed a $50 \%$ increase in the magnitude of the negative sea ice extent trend during summer by extending the 1979-2006 record by just four years. The corresponding increase for the Northern Hemisphere as a whole was $30 \%$. The results also show a strong seasonality in the regional and hemispheric sea ice extent and area trends. For January through May, the Northern Hemisphere trends actually become less negative, whereas, from June through September, the trends become increasingly more negative, reaching a minimum for the year in September, before reversing in October (Fig. 4). The seasonalities in trends for the nine Arctic regions are all quite different. The results presented here of the Arctic sea ice extent and area changes over the 32-yr period by season, region, and month add to the accumulating database of changes occurring within the climate system and provide a further basis for improved understanding of the processes driving the sea ice changes.

Acknowledgements. The authors thank Nicolo DiGirolamo and Alvaro Ivanoff for help in the preparation of the figures. We also acknowledge the National Snow and Ice Data Center for providing the DMSP SSMI and SSMIS daily gridded brightness temperatures used in developing the sea ice data sets. The authors gratefully acknowledge the support of NASA's Cryospheric Sciences Program for funding this work.

Edited by: E. Hanna

\section{References}

Cavalieri, D. J., Parkinson, C. L., Gloersen, P., Comiso, J. C., and Zwally, H. J.: Deriving long-term time series of sea ice cover from satellite passive-microwave multisensor data sets, J. Geophys. Res., 104, 15,803-15,814, 1999.

Cavalieri, D. J., Parkinson, C. L., DiGirolamo, N., and Ivanoff, A.: Intersensor calibration between F13 SSMI and F17 SSMIS for global sea ice data records, IEEE Geosci. Remote Sens. Lett., 9, 233-236, doi:10.1109/LGRS.2011.2166754, 2012.

Meier, W. N., Stroeve, J., and Fetterer, F.: Whither Arctic sea ice? A clear signal of decline regionally, seasonally and extending beyond the satellite record, Ann. Glaciol., 46, 428-434, doi:10.3189/172756407782871170, 2007.

Nicholls, N.: Commentary and analysis: The insignificance of significance testing, B. Am. Meteorol. Soc., 82, 981-986, 2001.

Parkinson, C. L. and Cavalieri, D. J.: Arctic sea ice variability and trends, 1979-2006, J. Geophys. Res., 113, C07003, doi:10.1029/2007JC004558, 2008.

Parkinson, C. L. and Cavalieri, D. J.: Antarctic sea ice variability and trends, 1979-2010, The Cryosphere, 6, 871-880, doi:10.5194/tc-6-871-2012, 2012.

Parkinson, C. L., Cavalieri, D. J., Gloersen, P., Zwally, H. J., and Comiso, J. C.: Arctic sea ice extents, areas, and trends 19781996, J. Geophys. Res., 104, 20837-20856, 1999.

Santer, B. D., Wigley, T. M. L., Boyle, J. S., Gaffen, D. J., Hnilo, J. J., Nychka, D., Parker, D. E., and Taylor, K. E.: Statistical significance of trends and trend differences in layer-average atmospheric temperature time series, J. Geophys. Res., 105, 73377356, 2000.

Stroeve, J. C., Serreze, M. C., Holland, M. M., Kay, J. E., Maslanik, J., and Barrett, A. P.: The Arctic's rapidly shrinking sea ice cover: a research synthesis, Climatic Change, 110, 1005-1027 doi:10.1007/s10584-011-0101-1, 2012.

Vinnikov, K. Y., Cavalieri, D. J., and Parkinson, C. L.: A model assessment of satellite observed trends in polar sea ice extents, Geophys. Res. Lett., 33, L05704, doi:10.1029/2005GL025282, 2006.

Zabel, I. H. H. and Jezek, K. C.: Consistency in long-term observations of oceans and ice from space, J. Geophys. Res., 99, 1010910120, 1994. 